\title{
EFFECTS OF PROTEIN AND VITAMIN ADE ON GROWTH PERFORMANCE AND HAEMATO-BIOCHEMICAL PROFILE IN BROILER
}

\author{
M. Salahuddin, M. A. Miah* and N. Ahmad \\ Department of Physiology, Bangladesh Agricultural University, Mymensingh-2202, Bangladesh.
}

\begin{abstract}
The effects of additional supplementation of protein and vitamin ADE on growth performance and haemato-biochemical profile were studied in "Cobb 500" broiler chicks. The chicks were randomly divided into four equal groups ( $\mathrm{n}=5$ ). Group A was considered as control, fed only with commercial ration and other groups were supplemented with either $20 \%$ protein (group B) or $3 \mathrm{ml}$ vitamin ADE/liter D.W. (group C) or both of them (group D) in addition to commercial ration. Body weight was increased significantly $(\mathrm{p}<0.05)$ in all three treated groups and highest body weight was recorded in group D. Weights of different organs (liver, skin, legs, breast and viscera) were also varied significantly $(p<0.05)$ among the treated groups. Significant $(p<0.05)$ differences were observed among the groups for RBC and Hb but increase in PCV values were insignificant $(p>0.05)$. Serum transaminases (AST, ALT) and creatinine level decreased insignificantly but urea level significantly $(\mathrm{p}<0.05)$ varied among the treated groups. The study revealed that combined supplementation of protein and vitamin ADE result better in body weight and different organs weight gain.
\end{abstract}

Key words: Haematology, biochemical profile, growth performance and broiler

\section{INTRODUCTION}

Poultry industry is an important part of agriculture in our country. It has multi-faceted prospects, creation of employment, poverty alleviation and improved nutrition and women empowerment. Poultry meat contributes about $37 \%$ of total animal protein supply of Bangladesh (Ahmed, 2008) and both poultry meat and egg production account for more than $30 \%$ of all animal protein worldwide and the share is increasing by 2015 , poultry will account for $40 \%$ of all animal protein. Feed is an important factor for broiler production. Among feed ingredients protein costs is higher than others i.e. it involves about $15 \%$ of the total feed cost (Banerjee, 1992). Dietary protein is a major source of body protein. It is preferable to use high quality protein sources especially for broilers under heat stress (Temim et al., 2000). Poor quality or imbalanced protein can create metabolic stress which reduced growth performance. Protein enhances muscle building and vitamin ADE supplements will prevent the deficiency diseases, reduce stress and mortality rate (Wijtten et al., 2010; Sahin et al., 2001; Swain and Johri, 2000) Supplementation of protein and vitamin ADE with other feed increases feed intake, total digestibility and feed conversion ratio resulting an increase in daily weight gain as well as significantly increase growth rate of broiler which helps early gain of marketing age that is very important for profitable farming (Odunsi et al.,1999). Although several workers have stated different concentration of roteins for maximum growth in broilers (Serafin, 1982; Sinha and Verma, 1984; Rajini et al.,1998 and Urdaneta-Rincom et al., 2004), but limited information is available on combination of protein and vitamin ADE on growth and hemato-biochemical profiles on broilers. Considering the above facts, the present study was conducted to study the effects of additional supplementation of protein and Vitamin ADE on growth performances, on hematological parameters such as total erythrocyte count (TEC), hemoglobin (Hb) content, packed cell volume, on cardiohepatic and kidney function.

*Corresponding e-mail address: alam.dina@gmail.com

Copyright ( 2012 Bangladesh Society for Veterinary Medicine

All rights reserved 0239/2012 


\section{MATERIALS AND METHODS}

A total of 20, ten days old "Cobb 500" broiler chicks purchased from Kazi farm limited, were randomly divided into four equal groups $(\mathrm{n}=5)$ Group A was considered as untreated control, fed only with commercial ration, group B was supplemented with $20 \%$ protein (Jasoprot, protein concentrates, Jason Agrovet Ltd) in feed, group C was supplemented with vitamin ADE ( Acme Laboratories Ltd) (3 ml/liter drinking water ) and group D was supplemented with $20 \%$ protein in feed and vitamin $\mathrm{ADE}(3 \mathrm{ml} / \mathrm{liter}$ in drinking water) in addition to commercial ration. Initial body weight of each bird was recorded and kept them group wise. Fresh water was supplied to the broilers ad libitum. Feed supplementations were prepared on daily basis.Managements and rearing of birds were strictly followed according to standard broiler farming system. In order to prevent stress, shock, deficiencies and infections broiler chicks were routinely immunized and antibiotic premix were used as per recommendation of manufacturer. Proper hygienic and strict sanitary measures were also taken during the experimental periods.

The body weight of each bird was measured with the help of electric balance on the day 10 of age (0 day of experiment). We used 10 days old chicks for management advantages and to reduce the mortality rate and subsequently compared the data with same age of untreated control birds. All the birds were sacrificed processed and weights (live and dressed weight, weights of skin, legs, breast, visceral) were taken by electric balance to study the meat yield and growth characteristics at the end of the experiment (31 days of age).

Blood from each bird was collected at slaughter. A number of sterile test tubes containing anticoagulant $(3.8 \%$ Trisodium citrate solution) at a ratio of 1:10 were taken. The hematological studies were performed within two hours of collection.

Sera were prepared for biochemical (Creatinine, AST, ALT, and Urea) analyses according to standard procedures. Briefly, $3 \mathrm{ml}$ of blood was collected in the sterile glass test tube. The blood containing tubes were placed in a slanting position at room temperature for clotting. Then the tubes were incubated overnight in the refrigerator $\left(4^{\circ} \mathrm{C}\right)$. Then serum was collected. The sample was centrifuged at $1000 \mathrm{rpm}$ for 15 minutes to have a more clear serum. The serum samples were separated and stored at $-20^{\circ} \mathrm{C}$ till analysis.

Serum creatitinine, transaminases and urea were assayed by conventional enzymatic methods on a Hitachi 911 automated analyzer from Roche Diagnostics (Laval, QC, Canada) according to the manufacturer's specifications All data were expressed as mean \pm standard error and differences among the groups of birds were compared using one-way ANOVA with post-hoc Duncan's multiple range test. Statistical analysis was performed using SPSS software

\section{RESULTS AND DISCUSSION \\ Effects on Body Weight}

Body weight of different groups of birds is presented in Table 1. Body weight on (day 10 of age) day 0 of experiment was more or less similar. On day 7 of experiment significantly $(p<0.05)$ lower weight gain was recorded in group C compared to other treated groups. On day 14 and 21 the highest body weight was recorded in group D which was significantly $(\mathrm{p}<0.05)$ higher than others $(\mathrm{p}<0.05)$. It is evident that body weight increased significantly $(\mathrm{p}<0.05)$ in all groups of birds with advancement of age. However in group A, body weight gain was slower compared to others group. Among the treated groups highest weight gain was recorded in group D (1202 $\pm 16.4 \mathrm{~g})$ followed by group B and C.

Table 1. Effect of additional supplementation of protein and vitamin ADE on body weight (mean $\pm \mathrm{SE}$ ) of broilers

\begin{tabular}{|ccccc|}
\hline Groups & \multicolumn{4}{c|}{ Body weight (Gram) } \\
\cline { 2 - 5 } & Day 0 & Day 7 & Day 14 & Day 21 \\
\cline { 2 - 5 } Group A & $192 \pm 5.7$ & $391 \pm 7.4^{\mathrm{b}}$ & $735 \pm 20.0^{\mathrm{a}}$ & $980 \pm 78.7^{\mathrm{a}}$ \\
Group B & $190 \pm 7.9$ & $402 \pm 7.6^{\mathrm{b}}$ & $756 \pm 18.2^{\mathrm{a}}$ & $1199 \pm 5.5^{\mathrm{b}}$ \\
Group C & $191 \pm 9.6$ & $368 \pm 22.8^{\mathrm{a}}$ & $748 \pm 8.4^{\mathrm{a}}$ & $1190 \pm 14.1^{\mathrm{b}}$ \\
Group D & $189 \pm 7.4$ & $404 \pm 11.4^{\mathrm{b}}$ & $770 \pm 12.2^{\mathrm{b}}$ & $1202 \pm 16.4^{\mathrm{b}}$ \\
\hline
\end{tabular}

Figures followed by different superscript letter in the same column differ significantly $(\mathrm{p}<0.05)$. 
The increased body weight recorded in this experiment was consistent with the earlier reports of Serafin (1982), Sinha and Verma (1984), Muktar et al. (1985), Husseini et al. (1987), Nagra and Sethii (1993) and Rajini et al. (1998) who showed that, 20-24\% crude protein in broiler diet increases the body weight. Sahin et al. (2001) and Downs et al. (2003) observed that vitamin ADE significantly increase body weight gain in broiler. In this study, $20 \%$ protein and vitamin ADE supplementation with commercial diet highly promotes the body weight of broiler.

\section{Effects on weights of different organs}

The effects of protein and vitamin ADE supplementation on weights of different organs are presented in Table 2. The dressed weight increased significantly in all treated group $(p<0.05)$ and the highest weight was recorded in group D. The findings were similar with those of Pandey and Sunder (1990).

Breast weight in treatment group increased significantly $(\mathrm{p}<0.05)$ compared to control group. Though breast weight varies among treated groups but not significantly $(\mathrm{p}<0.05)$. The increased breast weight in the treated group may be due to increase anabolic activity of protein. This finding particularly agreed with Wijtten et al. (2004) who found that increase in dietary protein and threonine increased breast weight.

The highest liver weight was recorded in group D and lowest in group A. Significant $(\mathrm{p}<0.05)$ differences were observed among the groups. The present finding is similar with the earlier experiment of Shlig (2009) and Leeson et al. (1997). In case of skin, lowest weight was observed in control group A $(\mathrm{p}<0.05)$ compared to other three groups. No statistical differences were observed among protein and vitamin treated broilers. The present finding is consistent with that of Huyghebaert et al. (1996).

Table 2. Effect of additional supplementation of protein and vitamin ADE on weight (mean \pm SE) of different organs of broilers

\begin{tabular}{|ccccccc|}
\hline Groups & Liver & Skin & Leg & Viscera & Breast & Dressed weight \\
\hline Group A & $35.9 \pm 1.9^{\mathrm{a}}$ & $97 \pm 12.8^{\mathrm{a}}$ & $30.93 \pm 2.5^{\mathrm{a}}$ & $100.6 \pm 2.1^{\mathrm{a}}$ & $92.3 \pm 10.5^{\mathrm{a}}$ & $690 \pm 30^{\mathrm{a}}$ \\
Group B & $43.9 \pm 1.9^{\mathrm{c}}$ & $120.7 \pm 0.9^{\mathrm{b}}$ & $40.6 \pm 3.4^{\mathrm{b}}$ & $122.6 \pm 2.9^{\mathrm{b}}$ & $142.9 \pm 27.6^{\mathrm{b}}$ & $850 \pm 26.4^{\mathrm{b}}$ \\
Group C & $39.7 \pm 1.4^{\mathrm{b}}$ & $111.8 \pm 3.2^{\mathrm{b}}$ & $31.8 \pm 2.4^{\mathrm{a}}$ & $103.3 \pm 4.5^{\mathrm{a}}$ & $128.6 \pm 9.7^{\mathrm{b}}$ & $796.7 \pm 45.1^{\mathrm{b}}$ \\
Group D & $46.6 \pm 2.3^{\mathrm{c}}$ & $119.9 \pm 0.9^{\mathrm{b}}$ & $41.3 \pm 8^{\mathrm{c}}$ & $124.9 \pm 3.5^{\mathrm{b}}$ & $139.8 \pm 5.4^{\mathrm{b}}$ & $846.7 \pm 25.2^{\mathrm{b}}$ \\
\hline
\end{tabular}

Figures with different superscript letters in the same column differ significantly $(\mathrm{p}<0.05)$

The effects of protein and vitamin ADE supplementation on legs weight varied in the treated groups compared to control. The birds in treated groups showed the fluctuation in weight gain. But the amplitude of increase was found significantly $(\mathrm{p}<0.05)$ lower in group $\mathrm{C}$ and the control group. The result revealed that, the application of protein and vitamin ADE has significant effect on leg weight in birds. Similar observation was also made by Wijtten et al. (2010) and Hamano et al. (1998)

The highest visceral weight was recorded in group D and lowest in group A. Visceral weight increase greatly in group B and D treated with protein and slightly increase in group C treated with vitamin ADE but significant difference was observed among the groups. This finding differ to that of Shlig (2009) who observed reduced visceral weight after supplementation of Vitamin E and agreed with the report of Wijtten et al. (2010).

\section{Effects on haematological parameters}

The effects of dietary supplementation of protein and Vitamin ADE on total erythrocyte count (TEC), hemoglobin $(\mathrm{Hb})$ and packed cell volume $(\mathrm{PCV})$ are presented in Table 3. Dietary protein and vitamin ADE supplementation increased TEC significantly $(\mathrm{p}<0.05)$ in all treated groups at day 21 of experiments $(31$ days of age) compared to control. This finding was similar with findings of Elangovan et al. (2001) but differed to the findings of other authors (Donkoh et al.,1999; Odunsi et al., 1999, Ahmed et al., 2008).

The highest hemoglobin concentration was observed in treated group B and lowest in control group A. The control group had a significantly $(\mathrm{p}<0.05)$ lower $\mathrm{Hb}$ compared to others. This finding differed with earlier reports of Shlig (2009), Singh et al. (1992), Chandra et al. (1984) who observed significant decrease in hemoglobin 


\section{Salahuddin and others}

content after supplementation with protein and vitamin E. The variation of our data with those of earlier reports might be due to different strains of birds, time and duration of experiment and different management systems. However, the values of PCV were similar in all groups and statistically insignificant. This finding was consistent with report of Raju and Handa. (1999) and Ahmed et al. (2008) but not to Singh et al. (1992) and Iyayi et al. (2005).

Table 3. Hematological parameters (mean \pm SE) of broilers $(n=5)$ treated with protein and vitamin ADE

\begin{tabular}{|cccc|}
\hline Group & RBC (million $\left./ \mathrm{mm}^{3}\right)$ & HB $(\mathrm{g} / \mathrm{dl})$ & PCV \% \\
\hline Group A & $2.1 \pm 0.2^{\mathrm{a}}$ & $7.3 \pm 0.2^{\mathrm{a}}$ & $19.0 \pm 1.0$ \\
Group B & $2.7 \pm 0.2^{\mathrm{b}} 8.1 \pm 0.2^{\mathrm{b}}$ & $23.0 \pm 3.0$ & \\
Group C & $2.5 \pm 0.2^{\mathrm{b}}$ & $7.9 \pm 0.1^{\mathrm{b}}$ & $21.0 \pm 1.0$ \\
Group D & $2.6 \pm 0.2^{\mathrm{b}}$ & $8.0 \pm 0.2^{\mathrm{b}}$ & $21.6 \pm 1.5$ \\
\hline
\end{tabular}

Figures followed by different superscript letter in the same column differ significantly $(\mathrm{p}<0.05)$.

\section{Effects on bio-chemical parameters}

Table 4. Serum bio-chemical parameters (mean \pm SE) of broilers $(n=5)$ treated with protein and vitamin ADE

\begin{tabular}{|lcccc|}
\hline \multicolumn{1}{|c}{ Groups } & Creatinine (unit) & AST (unit) & ALT (unit) & Urea (unit) \\
\hline Group A & $0.5 \pm 0.1$ & $120 \pm 25.35$ & $10.83 \pm 4.53$ & $16 \pm 10.39^{\mathrm{a}}$ \\
Group B & $0.47 \pm 0.15$ & $112 \pm 33.15$ & $7.33 \pm 3.51$ & $13.67 \pm 0.58^{\mathrm{b}}$ \\
Group C & $0.40 \pm 0.10$ & $79.43 \pm 49.41$ & $9.77 \pm 7.01$ & $15.00 \pm 3.00^{\mathrm{b}}$ \\
Group D & $0.37 \pm 0.11$ & $102.66 \pm 16.02$ & $4.00 \pm 2.65$ & $21.33 \pm 6.02^{\mathrm{c}}$ \\
\hline
\end{tabular}

Figures with different superscript letter in the same column differ significantly $(\mathrm{p}<0.05)$.

Among the serum bio-chemical parameters, creatinine, aspertate aminotransferase (AST) and alanine transaminase (ALT) values were found insignificantly lower in all treated groups compare to control group (Table 4). The creatinine value was in contrast with the earlier report of Tauson et al. (1997) who found that creatinine level increase remarkably in response to dietary protein in mink and dogs. In case of AST, this finding was similar with that of Bayram et al. (2004) who found insignificant difference in different broiler groups treated with vitamin E. The values of ALT are also in consistent with those of Sahin et al. (2001), Park et al. (2004), and Hamad et al. (2011) but differed with that of Nkosi (2005).

The urea level in treated group D receiving protein and vitamin ADE was found to be significantly higher than others. Vitamin ADE could not alter the urea level greatly. Urea level of group B was apparently low compared to control group A. This finding was in agreement with the earlier experiment of Tauson et al. (1998) and Chandra et al. (1984).

\section{ACKNOWLEDGEMENT}

This work was supported by the National Science and Technology (NST) funded by the Ministry of Science and Technology (MOST), The People's Republic of Bangladesh.

\section{REFERENCES}

1. Ahmed F (2008). Problems of egg production remedy of it, in poultry farms. Punashcha. Reg no- DA. $1440: 14$

2. Banerjee GC (1992). Poultry. $3^{\text {rd }}$ edn., Oxford and IBH Publishing Co. Pvt. Ltd., New Delhi, pp. 168-172. 
3. Bayram I, Midilli M, Tuncer SD and Kilinc C (2004). The effects of supplementation of protein and mineral to the rations on some blood parameters of broilers. Indian Veterinary Journal 81(11):1213-1216.

4. Chandra M, Singh B, Singh N and Ahuja SP (1984). Hematological changes in nephritis in poultry induced by diets high in protein, high in calcium, containing urea, or deficient in vitamin A. Poultry Science 63(4):710-16

5. Downs KM, Norton RA, Maclin KS and Hess JB (2003). Potential of vitamin E and zinc-aminoacid complex for the reduction of cellulitis in broilers. Journal of Applied Animal Research 23(1): 25-32.

6. Donkoh A, Atuahene CC, Anang DM and Otori SK (1999). Chemical composition of solar dried blood meal and its effect on performance of broiler chickens. Animal Feed Science and Technology 81(3-4): 299307.

7. Leeson S and Zubair AK (1997). Nutrition of the broiler chicken around the period of compensatory growth. Poultry Science 76 (7): 992-999.

8. Mukhtar S, Aslam Z and Sarwar M (1985). Effect of varying protein levels on the performance of broiler chickens. Pakistan Veterinary Journal 5(3): 124-126.

9. Elangovan AV, Verma SVS, Sastry VRB and Singh SD (2001). Rapeseed meal as a protein supplement in diets for growing Japanese quail. Archiv fur Geflugelkunde. 65(3):114-117.

10. Hamad EM, Taha SH, Dawood A, Sitohy MZ and Abdel-Hamid M (2011). Protective effect of whey proteins against nonalcoholic fatty liver in rats. Lipids Health Disease 10:57.

11. HamanoY, Hamada Y, Miyahara M, Kobayashi S and Terashima Y (1998). Effects of dietary protein and energy on growth performance and muscle composition in broiler treated with clenbuterol. Asian Australasian Journal of Animal Science 911 (4): 391-397

12. Huyghebaert G and Pack M (1996). Effects of dietary protein content, addition of nonessential amino acids and dietary methionine to cysteine balance on responses to dietary sulphur containing amino acids in broilers. British Poultry Science 37(3): 623-639.

13. Husseini MD, Dab MF, Salem AJ and Dandan AM (1987). Effect of protein and energy levels and birds stocking density on the performance of broiler under elevated temperatures. Poultry Abstracts 14 (3): 60

14. Iyayi EA, Taiwo VO and Fagbohun AO (2005). Performance, carcass characteristics, haematological and histopathological studies of broilers fed (Mucuna utilis) bean meal based diets. Israel Journal Veterinary Medicine 60 (2): 51-58

15. Nagra SS and Sethii APS (1993). Energy and protein requirements of commercial broiler in hot-humid climate. Indian Journal of Animal Science 693(97): 761-766.

16. Nkosi CZ, Opoku AR and Terblanche SE (2005). Effect of pumpkin seed protein isolate on the activity levels of certain plasma enzymes in $\mathrm{CCl}_{4}$-induced liver injury in low-protein fed rats. Phytotherapy Research 19(4): 341-345.

17. Odunsi AA, Onifade AA and Babatunde GM (1999). Response of broiler chicks to virginimycin and dietary protein concentrations in the humid tropics. Archivosdezootecnia 48(183): 317-325

18. Park KJ, Kim HY, Chang BJ and Lee HH (2005). Ameliorative effects of soy 11S protein on liver damage and hyperlipidemia in alcohol-fed rats. Biopharma Bulletin 27(10):1636-41

19. Pandey NK and Sunder GS (1990). Carcass characteristics, meat yield and physio-chemical properties of meat of white leghorn cockerels. Indian Journal of Poultry Science 25:249-252.

20. Rajini RA, Jhanabalan S, Narahari D and Kumararaj R (1998). Influence of season, from of feed and dietary energy levels on broiler performance. Indian Journal of Poultry Science 33 (3): 341-348.

21. Raju K, and Handa MC (1999). Effect of ad lib feeding of whole wheat grains at varying levels of protein supplement in Soviet chinchilla broiler rabbits. Indian Journal of Animal Production and Management 15(2): 48-51.

22. Sahin N, Sahin K and Kucuk O (2001). Effects of vitamin E and vitamin A supplementation on performance, thyroid status and serum concentrations of some metabolites and minerals in broiler reared under heat stress $\left(20^{\circ} \mathrm{c}\right)$. Veterinary Medicine 46 (11-12):286-292. 


\section{Salahuddin and others}

23. Serafin JA (1982). Influence of protein level and supplemental methionine in in practical rations for young endangered masked bobwhite quail. Poultry Science 61(5): 985-990.

24. Shlig AA (2009). Effect of vitamin E and selenium supplement in reducing aflatoxicosis on performance and blood parameters in broiler chicks. Iraqi Journal of Veterinary Sciences 23: 97-103.

25. Singh A, Saga KC and Mahipal (1992). Hematological and biochemical studies on broiler chicks fed aflatoxin Bi after it's withdrawal. Indian Journal of Poultry Science 27 (3): 153-156.

26. Sinha RRP and Verma AK (1984). Effect of different levels of dietary protein on Japanese quail (Coturnix coturnix Japanica) feeding. Indian Journal of Animal Health 23(1):77-80.

27. Swain BK and Johri TS (2000). Effects of supplementation of combination of different level of vitamin E on relative weight of some organs in broilers. Indian Journal of Poultry Science 35(1):66-69.

28. Temim S, Chagneau AM, Guillaumin S, Michel J, Peresson R. and Tesseraud S ( 2000). Doses excess dietary protein improves growth performance and carcass characteristics in heat exposed chickens. Poultry Science 79(3): 312-317.

29. Tauson AH and Wamberg S (1998). Effects of protein supply on plasma urea and creatinine concentrations in female mink The Journal of Nutrition 128 (12): 2584-2586.

30. Urdaneta-Rincon M and Leeson S (2004). Muscle (Pectoralis major) protein turnover in young broiler chickens fed graded levels of lysine and crude protein. Poultry Science 83 (11):1897-903.

31. Wijtten PJ, Prak R, Lemme A and Langhout DJ (2004). Effect of different dietary ideal protein concentrations on broiler performance. British Poultry Science 45(4): 504-511.

32. Wijtten PJ, Hangoor E, Sparla JK and Verstegen MW (2010). Dietary amino acid levels and feed restriction affect small intestinal development, mortality, and weight gain of male broilers. Poultry Science 89(7): 1424-39. 